\title{
Kinetics of neomycin release from polylactide spheres and its antimicrobial activity
}

\section{Kinetyka uwalniania neomycyny z sfer polilaktydowych i ich aktywność mikrobiologiczna}

\author{
Agnieszka Gadomska-Gajadhur ${ }^{1, A, B, D}$, Paweł Ruśkowski ${ }^{1, A, C, E, F}$, Aleksandra Kruk ${ }^{3, B, D}$, Jolanta Mierzejewska ${ }^{2, B, C}$ \\ ${ }^{1}$ Chair of Polymer Chemistry and Technology, Faculty of Chemistry, Warsaw University of Technology, Poland \\ ${ }^{2}$ Chair of Drug and Cosmetics Biotechnology, Faculty of Chemistry, Warsaw University of Technology, Poland \\ ${ }^{3}$ Department of Pharmacognosy and Molecular Basis of Phytotherapy, Faculty of Pharmacy, Medical University of Warsaw, Poland \\ A - research concept and design; $\mathrm{B}$ - collection and/or assembly of data; $\mathrm{C}$ - data analysis and interpretation; \\ $D$ - writing the article; $E$ - critical revision of the article; $F$ - final approval of the article
}

\section{Address for correspondence \\ Paweł Ruśkowski}

E-mail: pawel.ruskowski@ch.pw.edu.pl

\section{Funding sources}

Financial support of Warsaw University of Technology,

Faculty of Chemistry is gratefully acknowledged.

Conflict of interest

None declared

Received on May 28, 2021

Reviewed on June 7, 2021

Accepted on June 29, 2021

Published online on July 30, 2021

\section{Cite as}

Gadomska-Gajadhur A, Ruśkowski P, Kruk A, Mierzejewska J. Kinetics of neomycin release from polylactide spheres and its antimicrobial activity. Polim Med. 2021;51(1):17-24. doi:10.17219/pim/139586

DOI

10.17219/pim/139586

Copyright

○ 2021 by Wroclaw Medical University

This is an article distributed under the terms of the

Creative Commons Attribution 3.0 Unported (CC BY 3.0)

(https://creativecommons.org/licenses/by/3.0/)

\begin{abstract}
Background. Neomycin is a natural aminoglycoside antibiotic produced by actinomycete Streptomyces fradiae. It exerts bacteriostatic and bactericidal activity against Gram-negative bacteria, certain Gram-positive bacteria and Mycobacterium tuberculosis. Neomycin inhibits the biosynthesis of bacterial proteins by impairing their life functions, leading to death of cells.

Objectives. To examine the effect of molecular weight of polylactide (PLA), the applied stabilizer as well as mixing speed used in the encapsulation process on the size of obtained spheres. Examination of the kinetics of neomycin release from the obtained PLA spheres and determination of the antimicrobial activity of the neomycin-containing spheres against selected strains of bacteria, yeast and fungi have also been necessary.
\end{abstract}

Materials and methods. Polylactide $\left(\mathrm{M}_{\mathrm{n}} 3000-40,000 \mathrm{~g} / \mathrm{mol}\right)$ was obtained in-house. Other materials used in the study were as follows: L-lactic acid (PLLA; $M_{n} 66,500 \mathrm{~g} / \mathrm{mol}$ and 86,000 $\left.\mathrm{g} / \mathrm{mol}\right)$, polyvinyl alcohol (PVA) as a stabilizer of emulsion ( $\mathrm{M}_{\mathrm{w}} 30,000 \mathrm{~g} / \mathrm{mol}$, 130,000 $\mathrm{g} / \mathrm{mol}$; degree of hydrolysis $88 \%$ ) as well as dichloromethane, p.a. and dimethyl sulfoxide (DMSO), p.a. as solvents. Distilled water was obtained in-house. Neomycin sulfate was used for encapsulation; phosphate (pH7.2) and acetate (pH 4.5) buffers were used for the examination of the active pharmaceutical ingredient (API) dissolution profile. Antimicrobial activity was tested using commercial cell lines and the following media: Mueller-Hinton agar (MHA), Mueller-Hinton broth (MHB), yeast extract peptone dextrose (YPD), and potato dextrose agar (PDA).

Results. Neomycin-containing PLA spheres were obtained using an emulsion method. The average molecular weight of PLA, the average molecular weight of PVA and mixing speed on the size of obtained spheres were investigated. Furthermore, the profile of API dissolution from the spheres and antimicrobial activity of neomycin-containing spheres against certain strains of bacteria, yeast and fungi were determined.

Conclusions. We demonstrated that efficient encapsulation of neomycin requires spheres of a $<200 \mathrm{~mm}$ diameter.

Key words: encapsulation, polyesters, drug delivery systems 


\section{Streszczenie}

Wprowadzenie. Neomycyna jest naturalnym antybiotykiem aminoglikozydowym produkowanym przez promieniowce Streptomyces fradiae. Działa bakteriostatycznie i bakteriobójczo na bakterie Gram-ujemne, niektóre bakterie Gram-dodatnie oraz na Mycobacterium tuberculosis. Neomycyna hamuje biosyntezę białek bakteryjnych poprzez upośledzenie ich funkcji życiowych, prowadząc do śmierci komórek.

Cel pracy. Celem pracy było zbadanie wpływu masy cząsteczkowej polilaktydu (PLA), zastosowanego stabilizatora oraz szybkości mieszania stosowanej w procesie enkapsulacji na wielkość otrzymanych sfer. Niezbędne było również zbadanie kinetyki uwalniania neomycyny z otrzymanych sfer PLA oraz określenie aktywności antymikrobiologicznej ser zawierających neomycynę wobec wybranych szczepów bakterii, drożdży i grzybów.

Materiał i metody. Polilaktyd ( $\mathrm{M}_{\mathrm{n}} 3000-40000 \mathrm{~g} / \mathrm{mol}$ ) zsyntetyzowano we własnym zakresie. Inne materiały użyte w badaniach to: kwas mlekowy (PLLA) ( $M_{n} 66500 \mathrm{~g} / \mathrm{mol}$ i $86000 \mathrm{~g} / \mathrm{mol}$ (Nature Works)), poli(alkohol winylowy) (PVA) jako stabilizator emulsji ( $M_{\mathrm{w}} 30000 \mathrm{~g} / \mathrm{mol}, 130 \mathrm{o00} \mathrm{g} / \mathrm{mol}$ oraz stopień hydrolizy 88\%, Mowiol) oraz dichlorometan (cz.d.a.), dimetylosulfotlenek (cz.d.a.) jako rozpuszczalniki. Wodę destylowaną uzyskano na miejscu. Do enkapsulacji stosowano siarczan neomycyny (Sigma-Aldrich); Do badania profilu rozpuszzzania API zastosowano bufory fosforanowe (pH 7,2) i octanowe (pH 4,5). Aktywność antymikrobiologiczną zbadano przy użyciu komercyjnych linii komórkowych i następujących pożywek: agar Muellera-Hinton, bulion Muellera-Hinton, ekstrakt drożdżowy z peptonem z dekstrozą i ziemniaczany agar z dekstrozą.

Wyniki. Polilaktydowe sfery zawierające neomycynę otrzymano metodą emulsyjną. Zbadano wpływ średniego ciężaru cząsteczkowego polilaktydu, średniego ciężaru cząsteczkowego PVA oraz szybkości mieszania na rozmiar otrzymanych sfer. Ponadto wyznaczono profil uwalniania API ze sfer i aktywność antymikrobiologiczną wobec wybranych szczepów bakterii, drożdży i grzybów strzępkowych.

Wnioski. Wykazano, że neomycyna efektywnie enkapsuluje w sferach o średnicy $<200 \mathrm{~nm}$.

Słowa kluczowe: enkapsulacja, poliestry, systemy dostarczania leków

\section{Background}

Controlled-release drug delivery systems (DDS) are a modern form of medicines. Compared to conventional dosage forms, they are characterized by a long-lasting therapeutic effect, improved biodistribution of active pharmaceutical ingredient (API) and minimization of toxic adverse reactions. ${ }^{1}$ As a result, they increase the therapeutic index of conventional pharmaceuticals. ${ }^{2}$ Among the recently developed DDSs available on the market, ${ }^{3}$ polymeric spheres are distinguished by various applications. ${ }^{4}$

Neomycin is a natural aminoglycoside antibiotic produced by the actinomycete Streptomyces fradiae (Fig. 1). It has bacteriostatic and bactericidal activity against Gramnegative bacteria, certain Gram-positive bacteria and Mycobacterium tuberculosis. ${ }^{5}$ Neomycin inhibits the biosynthesis of bacterial proteins by impairing their life functions, leading to cell death. Despite its broad spectrum of activity, neomycin is rarely used due to its harmful effect on the inner ear and kidneys (oto- and nephrotoxicity).

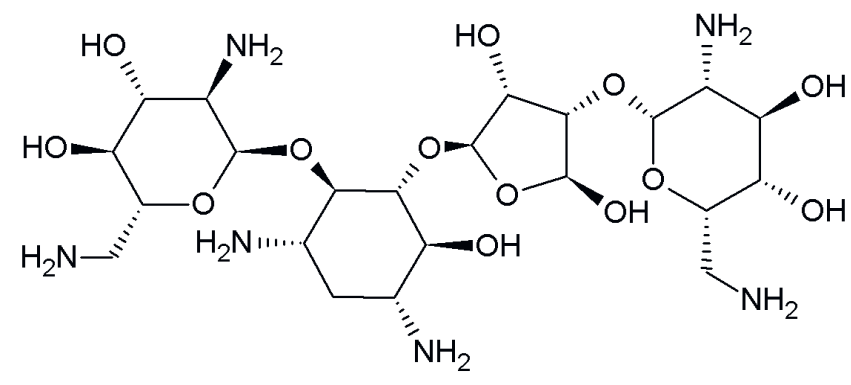

Fig. 1. Neomycin
Therefore, it is applied mainly externally in diseases of the skin, eyes and mucous membranes, or administered parenterally in the treatment of septicemia. ${ }^{6}$ For these reasons, efforts have been undertaken to develop novel, more valuable forms of neomycin administration in an attempt to improve its absorption and minimize its toxic adverse effects. ${ }^{7}$

Polymeric spheres bring hope to current limitations related to the delivery of neomycin. ${ }^{8}$ The spheres are ball-shaped particles, in which the active substance may be bound to the polymer matrix (prodrugs), suspended therein or adsorbed on their surface. ${ }^{9}$ The systems for delivering antibiotics within a polymer matrix ensure a slow release of API to the body, ${ }^{10}$ which reduces adverse effects and increases the therapeutic index of API. ${ }^{11}$

Polymer spheres used in DDS have diameters of 10$300 \mathrm{~nm}$. It is believed that small spheres (less than $100 \mathrm{~nm}$ in diameter) show better biodistribution within the body and are less prone to premature degradation by phagocytic cells of the immune system. ${ }^{12}$ However, it should be noted that due to the size and structural complexity of their molecules, encapsulation of some APIs in polymer matrices requires large spheres (over $100 \mathrm{~nm}$ in diameter) and also long-chain polymers. ${ }^{13}$ An example of such API is neomycin, which is characterized by a complex structure of 4 aminoglycoside rings. ${ }^{14}$

The polymer widely used in DDS is polylactide (PLA), a biocompatible and biodegradable aliphatic polyester. ${ }^{15}$ Within the organism, it undergoes decomposition to nontoxic products (carbon dioxide and water) that are readily eliminated. Polylactide consists of linearly linked moieties 

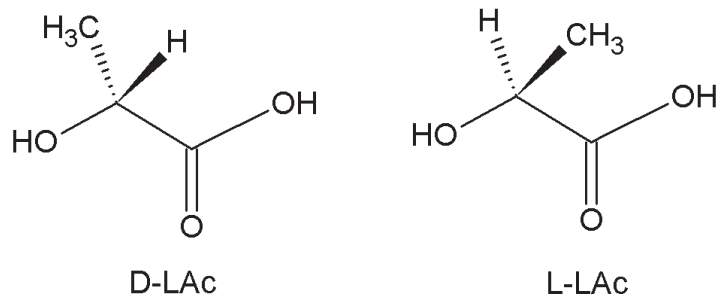

Fig. 2. Enantiomers of lactic acid

of lactic acid (LA). ${ }^{16}$ Since LA exists in 2 enantiomeric forms (Fig. 2), it is possible to obtain polymers of various configurations at their chiral centers and, thus, different physical properties ${ }^{17}$ Homochiral PLA that consists solely of molecules of either L-lactic acid (PLLA) or D-lactic acid (PDLA) is characterized by high mechanical strength and long biodegradation time that improves as the carbon chain lengthens. Heterochiral polylactide that contains both enantiomers of LA in its structure is more elastic and undergoes biodegradation more readily. ${ }^{18}$ Only the L-isomer of LA is metabolized in the body, while the D-enantiomer may accumulate in tissues leading to acidification of the body. ${ }^{19}$ Therefore, PLLA having a low molecular weight and containing several percent of the D-monomer is most relevant for pharmaceutical applications. ${ }^{20}$

The purpose of this study was to examine the effects of the molecular weight of PLA, the applied stabilizer as well as the mixing speed used in the encapsulation process on the size of obtained spheres. Examination of the kinetics of neomycin release from the obtained PLA spheres and determination of the antimicrobial activity of the neomycin-containing spheres against selected strains of bacteria, yeast and fungi have also been necessary.

\section{Materials and methods}

\section{Material}

Poly-L-lactide $\left(\mathrm{M}_{\mathrm{n}} 3000-40,000 \mathrm{~g} / \mathrm{mol}\right)$ used for preparing the spheres has been obtained in-house. Other materials used in the study were as follows: PLLA $\left(M_{n} 66,500 \mathrm{~g} / \mathrm{mol}\right.$ and $86,000 \mathrm{~g} / \mathrm{mol}$ (Nature Works, Minnetonka, USA)), polyvinyl alcohol (PVA) as a stabilizer of emulsion $\left(\mathrm{M}_{\mathrm{w}}\right.$ $30,000 \mathrm{~g} / \mathrm{mol}$ and $130,000 \mathrm{~g} / \mathrm{mol}$; degree of hydrolysis $88 \%$, Mowiol ${ }^{\circledR}$; Sigma-Aldrich, St. Louis, USA) as well as dichloromethane, p.a. and dimethyl sulfoxide, p.a. (POCH S.A., Gliwice, Poland) as solvents. Distilled water was obtained in-house. Neomycin sulphate (Sigma-Aldrich) was used for encapsulation; phosphate ( $\mathrm{pH} 7.2)$ and acetate $(\mathrm{pH} 4.5)$ buffers $(\mathrm{POCH})$ were used for the examination of the API dissolution profile. Antimicrobial activity was tested using commercial cell lines and the following media: MuellerHinton agar (MHA), Mueller-Hinton broth (MHB), yeast extract peptone dextrose (YPD), and potato dextrose agar (PDA) purchased from Merck Millipore (Burlington, USA) or BioCorp (Issoire, France). As a control, antibiotic with a well-established antimicrobial activity was used - either Amphotericin B against yeast and filamentous fungi, or Ampicillin sodium salt against bacteria. These were purchased from BioShop (Dourges, France).

\section{Preparation of neomycin-containing spheres}

The neomycin-containing spheres were prepared employing an emulsion method. At first, the following solutions of polymers having various molecular weights were prepared: a 1\% wt solution of PLA in dichloromethane and $0.1 \%$ wt solution of polyvinyl alcohol (PVA) in distilled water. The PVA solution $(100 \mathrm{~mL})$ was placed in a roundbottom flask immersed in a water bath that was standing on a magnetic stirrer (RTC Basic IKA; Sigma-Aldrich) and was provided with a temperature controller (ETS-D5 IKA). The temperature was set at $25^{\circ} \mathrm{C}$ and the stirring speed at $600 \mathrm{~min}^{-1}$ or $1200 \mathrm{~min}^{-1}$. Next, neomycin (5\% wt relative to PLLA) was added to the above solution. After thoroughly mixing the solution and stabilizing experiment conditions, PLLA solution ( $5 \mathrm{~mL}$ ) was added dropwise within $15 \mathrm{~min}$ through a pressure-equalizing dropping funnel, and the obtained suspension of spheres was stirred for $1 \mathrm{~h}$ at $25^{\circ} \mathrm{C}$ to evaporate the solvent. The flask content was filtered through a $3 G$ sintered glass filter funnel and then analyzed using dynamic light scattering (DLS).

Empty spheres were prepared analogously as the APIcontaining spheres, except for the active substance addition step.

\section{Analytical methods}

The size ( $d$ - diameter) of the obtained spheres was determined with DLS using Zetasizer Nano Z.S. from Malvern Instruments (Malvern, UK). The measurements were performed in polystyrene cuvettes. The UV-VIS spectra for determining the dissolution profile and optical density of the cultures were recorded using the Synergy H4 microplate reader from BioTek (Winooski, USA).

\section{Release profile}

The profile of API release from the spheres was determined from a calibration curve. The calibration curve of the absorbance of the aqueous solution of neomycin was measured at a concentration of $0.5 \mathrm{mg} / \mathrm{mL}, 0.25 \mathrm{mg} / \mathrm{mL}$, $0.125 \mathrm{mg} / \mathrm{mL}$, and $0.067 \mathrm{mg} / \mathrm{mL}$. The tests have covered suspensions of neomycin-containing spheres (without any pre-treatment) mixed with the acetate or phosphate buffer $(1: 1 \mathrm{v} / \mathrm{v})$ and the buffers not containing the spheres. Samples of the solutions were placed in wells of 96-well $200 \mu \mathrm{L}$ NuncTM plates (Thermo Fisher Scientific, Waltham, USA) and then incubated at $37^{\circ} \mathrm{C}$. At appropriate time 
intervals, absorbance was measured with spectrophotometry at the wavelength of neomycin maximum absorption $\lambda=360 \mathrm{~nm}$.

\section{Antimicrobial activity}

Antimicrobial activities of neomycin-containing spheres, empty spheres and neomycin were tested against bacteria, yeast and filamentous fungi. Inhibitory activity against bacteria and yeast was determined using 2 methods: tests on a solid medium and in a liquid medium.

The following microorganisms were used for tests: Staphylococcus aureus ATCC 6538, Escherichia coli ATCC 8739, Bacillus subtilis ATCC 6633, Salmonella typhimurium ATCC 14028 bacteria, Candida albicans ATCC 10231 yeast, Aspergillus niger ATCC 16404 mould and Colletotrichum coccodes MC 1, Fusarium oxysporum M.F. 5, and Fusarium sambucinum M.F. 1 filamentous fungi, received from the IHAR-PIB collection of Plant Breeding and Acclimatization Institute (Młochów, Poland).

\section{Preparation of cultures of bacteria and yeast}

A sterile loop full of material from a single colony of bacterium or yeast was used to inoculate $10 \mathrm{~mL}$ of liquid $\mathrm{MHB}$ or YPD medium in a $100 \mathrm{~mL}$ Erlenmeyer flask. Cultures were incubated overnight (about $18 \mathrm{~h}$ ) at $37^{\circ} \mathrm{C}$, shaking at $200 \mathrm{rpm}$ using Benchtop shaker LabCompanion SI-600R (Jeio Tech, Daejeon, South Korea). Next, the overnight cultures were diluted in fresh medium (MHB or YPD) to desire suspension of colony-forming units per $\mathrm{mL}-10^{8}$ $\mathrm{cfu} / \mathrm{mL}$ or $10^{5} \mathrm{cfu} / \mathrm{mL}$, based on the previously prepared growth curves for each microorganism.

\section{Preparation of the tested solutions}

Neomycin, ampicillin and amphotericin were dissolved in sterile dimethyl sulfoxide (DMSO) to obtain concentrations of $20 \mathrm{mg} / \mathrm{mL}$. Suspensions of the spheres containing the active substance and suspensions of empty spheres were added directly to the corresponding medium, without any pre-treatment.

\section{Tests of antimicrobial activity on a solid medium}

Briefly, $100 \mu \mathrm{L}$ of cell suspension of $10^{8} \mathrm{cfu} / \mathrm{mL}$ was distributed evenly on a suitable medium (MHA for bacteria or YPDA for yeast) and allowed to dry. Disks of Whatman paper ( $5 \mathrm{~mm}$ in diameter, 3MM; Sigma-Aldrich) were placed on the seeded agar plates, and $10 \mu \mathrm{L}$ of the samples were prepared as above (neomycin solution, empty spheres, neomycin-containing spheres and control antibiotics, respectively) and the suitable solvents were applied to the medium. The samples were incubated at $37^{\circ} \mathrm{C}$ for $24 \mathrm{~h}$. After incubation, microbial growth inhibition zones were measured for the tested samples, pure substances and the solvent, and the results were compared to the zones of microbial growth inhibition obtained for the control antibiotics (for bacteria: ampicillin, for yeast: amphotericin). Sample activity was determined by measuring the diameter of inhibition of the growth zone.

\section{Tests of activity in a liquid medium}

Briefly, $100 \mu \mathrm{L}$ of appropriate medium (MHB for bacteria and YPD for yeast) and $20 \mu \mathrm{L}$ of the tested samples (solution of neomycin, empty spheres and neomycin-containing spheres, respectively) were placed in wells of 96well plates. Next, $100 \mu \mathrm{L}$ of microorganisms from the suspension of $10^{5} \mathrm{cfu} / \mathrm{mL}$ was added to each well. The plates were placed in an incubator shaker $\left(200 \mathrm{~min}^{-1}\right)$ at $37^{\circ} \mathrm{C}$ for $24 \mathrm{~h}$. After $24 \mathrm{~h}$ of incubation, optical density (OD) of the cultures provided with inhibitors was measured using the spectrophotometric method at the wavelength $\lambda=600 \mathrm{~nm}$, and the results were compared to the OD of the controls (without the spheres or free antibiotics). Antimicrobial activity was calculated from the equation (1):

$$
\text { activity }=\frac{\mathrm{OD}}{\mathrm{OD}_{\text {control }}} \times 100 \%
$$

where:

OD - optical density of a culture of microorganisms with the addition of the active substance or spheres and $\mathrm{OD}_{\text {control }}$ - optical density of a culture of microorganisms without the addition of the active substance.

\section{Tests of activity against filamentous fungi}

Briefly, $1 \mathrm{~mL}$ of the tested preparation (solution of neomycin, empty spheres or neomycin-containing spheres, respectively) was added to $100 \mathrm{~mL}$ of dissolved PDA medium. The prepared mixtures were poured into Petri dishes and allowed to solidify. Next, mycelial disks (diameter: $6 \mathrm{~mm}$ ) were cut out of the actively growing fungal mycelium on PDA and transferred onto the Petri dishes containing the tested and reference (without the addition of active substances) preparations, respectively. ${ }^{21}$ The Petri dishes were incubated at $25^{\circ} \mathrm{C}$ for $3-5$ days, depending on the fungal growth rate. After incubation, dimensions of the zones of fungal growth in the presence of special preparations were measured. Next, it was compared to those of the reference samples. The activity of the preparations was calculated from the equation (2):

$$
\text { activity }=\frac{\mathrm{d}_{\text {control }}-\mathrm{d}}{\mathrm{d}_{\text {control }}} \times 100 \%
$$

where:

$\mathrm{d}[\mathrm{mm}]$ - the diameter of the zone of fungal growth in the presence of the tested preparation and $\mathrm{d}_{\text {control }}[\mathrm{mm}]$ - the diameter of the zone of fungal growth without the addition of the active substance. 


\section{Results}

\section{Preparation of neomycin-containing spheres}

Effects of molecular weights of PLLA $\left(M_{n}\right)$ and PVA $\left(\mathrm{M}_{\mathrm{w}}\right)$ and the mixing rate on the diameter of neomycincontaining spheres were examined (Fig. 3,4).

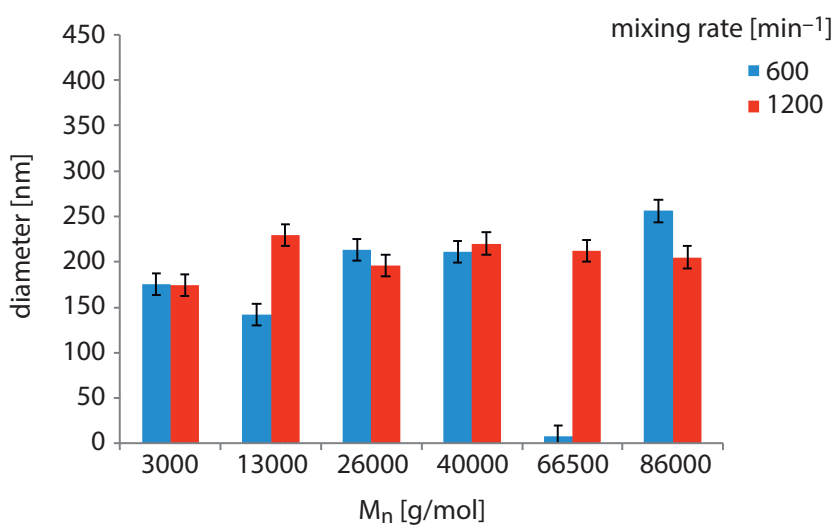

Fig. 3. Diameter of the spheres as a function of the average molecular weight of L-lactic acid (PLLA) and the mixing speed ( $M_{w}$ polyvinyl alcohol (PVA) 30,000 g/mol)

$M_{n}$ - number-average molecular weight; $M_{w}$ - weight-average molecular weight.

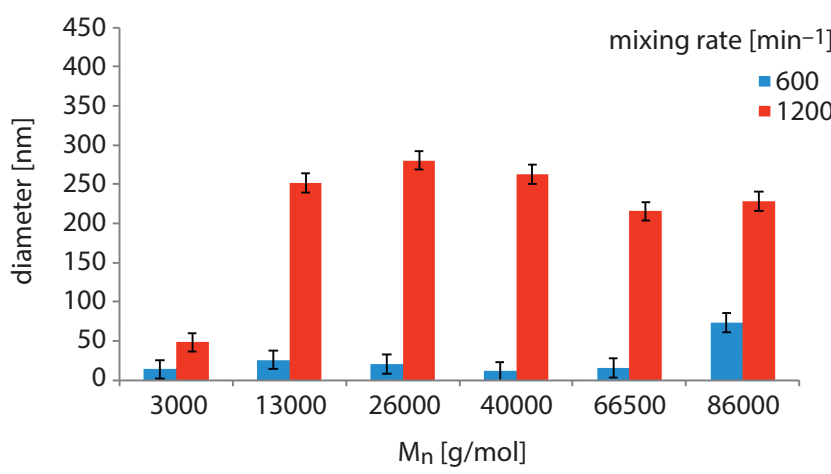

Fig. 4. Diameter of the spheres as a function of the average molecular weight of L-lactic acid (PLLA) and the mixing speed ( $M_{w}$ polyvinyl alcohol (PVA) $130,000 \mathrm{~g} / \mathrm{mol}$ )

$M_{n}$ - number-average molecular weight; $M_{w}$ - weight-average molecular weight.

\section{DLS analysis}

The size of the obtained spheres was measured using the DLS method by determining a relationship between light scattering intensity and the number of particles of a certain radius. The relation between the fraction of particle size and the radius of the particles is shown in Fig. 5. In some cases, 2 maxima of particle size distribution could be seen (Fig. 6).

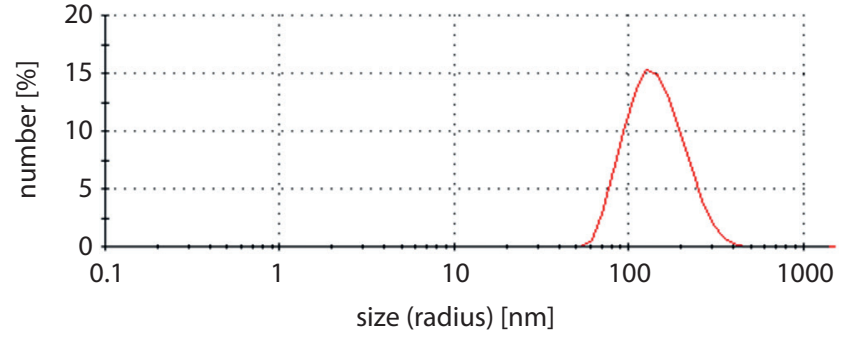

Fig. 5. The relationship between the fraction of spheres at a particular size and the radius of the spheres

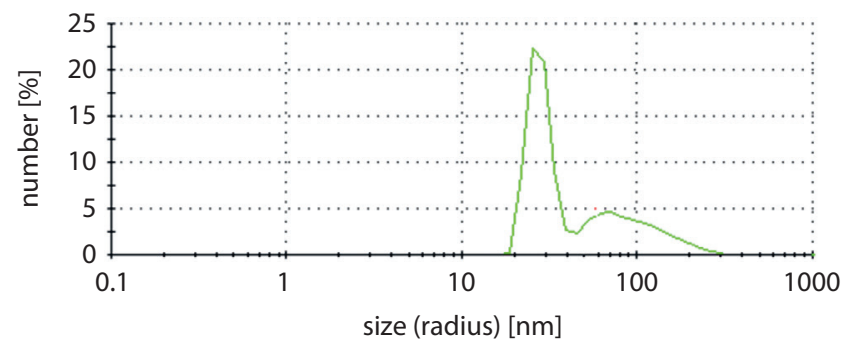

Fig. 6. Two fractions of spheres of different sizes

\section{API release profile}

The profile of API release from the PLA spheres was established by determining a relationship between absorbance (proportional to antibiotic concentration) and incubation time of the samples (Fig. 7). The examined spheres had diameters of $150 \mathrm{~nm}$ and $200 \mathrm{~nm}$. The measurements were carried out in acetate buffer $(\mathrm{pH} 4.5)$ and in phosphate buffer $(\mathrm{pH}$ 7.2) to compare release kinetics in the media of various $\mathrm{pH}$.

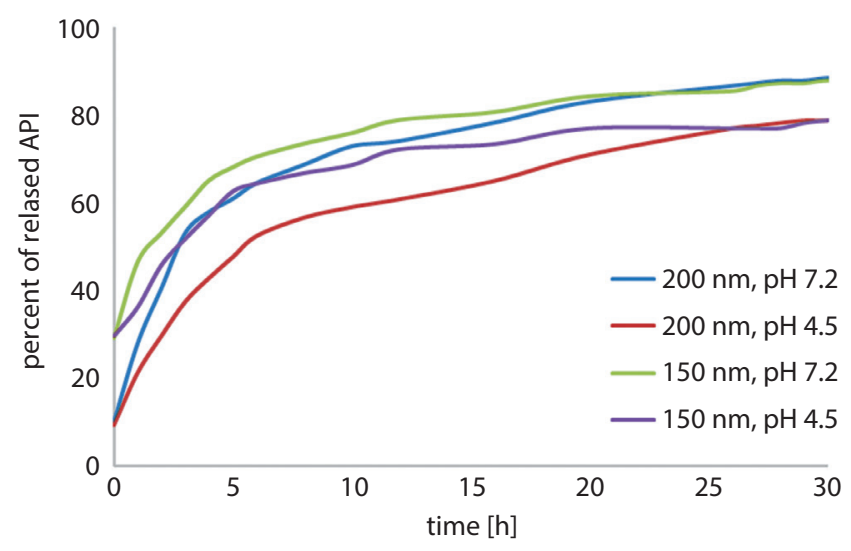

Fig. 7. Profiles of neomycin release from L-lactic acid (PLLA) spheres having diameters of $150 \mathrm{~nm}$ and $200 \mathrm{~nm}$ in the acetate or phosphate buffers

API - active pharmaceutical ingredient.

\section{Antimicrobial activity of the neomycin-containing spheres}

Tests of activity on a solid medium

Antimicrobial activity of the empty spheres, neomycin and neomycin-containing spheres (diameter ca. $200 \mathrm{~nm}$ ) 
Table 1. Antimicrobial activity (diameter of inhibition of growth zone) of neomycin, neomycin-containing spheres, empty spheres and amphotericin and ampicillin against bacteria and yeast on a solid medium

\begin{tabular}{|c|c|c|c|c|c|}
\hline Drug & E. coli & S. aureus & B. subtilis & S. typhimurium & C. albicians \\
\hline \multicolumn{6}{|c|}{ Diameter of inhibition of growth zone [mm] } \\
\hline Neomycin & 30.0 & 30.0 & 36.0 & 30.0 & 20.9 \\
\hline Spheres with neomycin & 29.0 & 21.0 & 32.0 & 28.0 & 20.1 \\
\hline Empty spheres & 0 & 0 & 27.1 & 0 & 0 \\
\hline Amphotericin & - & - & - & - & 13.0 \\
\hline Ampicillin & 24.0 & 26.0 & 28.0 & 26.0 & - \\
\hline
\end{tabular}

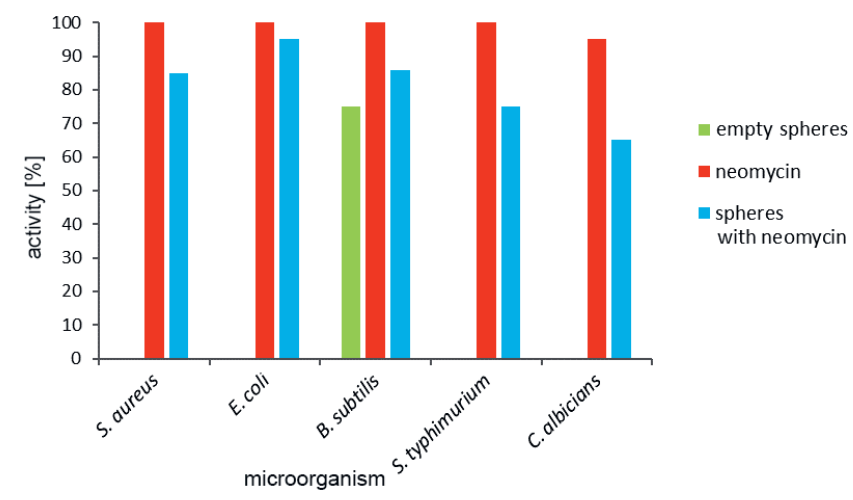

Fig. 8. Antimicrobial activity (percent of inhibition of the growth of a microorganism) of neomycin, neomycin-containing spheres and empty spheres against bacteria and yeast on a liquid medium

against bacteria and yeast has been tested on the solid medium (Table 1). The inhibitory effect of the sample was determined by the size of the inhibition of the growth zone. An inhibitory effect of DMSO (solvent for neomycin) on the tested strains has been excluded.

\section{Tests of activity in a liquid medium}

To examine the accuracy of the tests on a solid medium, the activity of the tested preparations against bacteria and yeast was examined using a liquid medium (Fig. 8). The toxicity of preparation against a given strain was proven by a $50 \%$ decrease in OD of the corresponding culture.

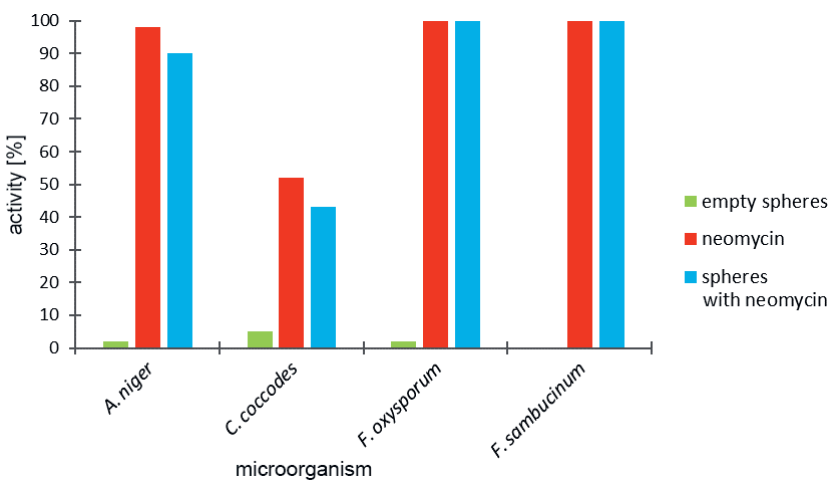

Fig. 9. Antimicrobial activity (percent of culture growth inhibition) of neomycin, neomycin-containing spheres and empty spheres against filamentous fungi

\section{Tests of activity against filamentous fungi}

The tests have also examined antimicrobial activity against filamentous fungi on a solid medium (Fig. 9). As in previous cases, neomycin-containing spheres having a diameter of ca. $200 \mathrm{~nm}$ were used for this purpose, with empty spheres serving as a reference sample. A 50\% cell death was adopted as a threshold of toxicity of a tested sample against a given strain.

\section{Discussion}

\section{Preparation of neomycin-containing spheres}

The effect of the number-average molecular weight, $M_{n}$, of PLLA, the weight-average molecular weight, $M_{w}$, of polyvinyl alcohol and stirring speed on the size of obtained spheres were examined (Fig. 3,4). In the case of poly-L-lactide with $M_{n} 3000 \mathrm{~g} / \mathrm{mol}$ and PVA with $M_{w} 130,000 \mathrm{~g} / \mathrm{mol}$, the diameter of the spheres was minimal (approx. $50 \mathrm{~nm}$ ). On the other hand, larger spheres, 230-300 nm in diameter, were obtained from higher molecular weight polymers $\left(\mathrm{M}_{\mathrm{n}}\right.$ 13,000-86,000 g/mol) (Fig. 4).

We found that the effect of the average molecular weight $\left(\mathrm{M}_{\mathrm{w}}\right)$ of polyvinyl alcohol on the diameter of formed spheres is associated with the applied mixing speed $\left(600 \mathrm{~min}^{-1}\right.$ or $1200 \mathrm{~min}^{-1}$ ). In PVA of $\mathrm{M}_{\mathrm{w}} 30,000 \mathrm{~g} / \mathrm{mol}$, the differences in sphere diameters were minor for each mixing speed (Fig. 3). At the mixing speed of $600 \mathrm{~min}^{-1}$, the diameter of the obtained spheres was in the range of 140-260 nm (with 1 exception), while at $1200 \mathrm{~min}^{-1}$, it was in the range of $170-230 \mathrm{~nm}$.

According to the manufacturer's data, the viscosity of PVA solutions increases with elevations in $\mathrm{M}_{\mathrm{w}}$ (at $20^{\circ} \mathrm{C}$, the viscosity of a $1 \%$ aqueous solution of PVA having $\mathrm{M}_{\mathrm{w}}$ $30,000 \mathrm{~g} / \mathrm{mol}$ is $4 \mathrm{cP}$, while for PVA having $\mathrm{M}_{\mathrm{w}} 130,000$ it increases to $18 \mathrm{cP}$ ). As a rule, the spheres obtained at the mixing speed $600 \mathrm{~min}^{-1}$, with the use of PVA having $M_{w} 130,000 \mathrm{~g} / \mathrm{mol}$, were much smaller (less than $70 \mathrm{~nm}$ in diameter) than those obtained at the mixing speed $1200 \mathrm{~min}^{-1}$ (200-300 nm) (Fig. 4). Therefore, to obtain spheres larger than $200 \mathrm{~nm}$, one should appropriately increase the mixing speed. 
We also observed that the volume of the spheres obtained from PLLA having $M_{n} 3,000 \mathrm{~g} / \mathrm{mol}$ was presumably too small to accommodate a neomycin molecule inside it. Hence, PLLA of a higher number average molecular weight was used in further investigations.

\section{DLS analysis of neomycin-containing spheres}

The graph illustrating a relation of the number of samesize spheres (measured with the DLS method) and their radius resembles the Gaussian curve (normal distribution) (Fig. 5). In some cases, curves showing 2 distinct maxima have been recorded (Fig. 6). Two maxima indicate the presence of 2 fractions of spheres varying in diameters. The spheres from the $1^{\text {st }}$ fraction had a small diameter, less than $100 \mathrm{~nm}$, whereas those from the $2^{\text {nd }}$ fraction had a much larger diameter, over $150 \mathrm{~nm}$. The graph showing only 1 single maximum of the sphere size that corresponds to the diameter of the spheres under $100 \mathrm{~nm}$ was related to low stirring speed $\left(600 \mathrm{~min}^{-1}\right)$ for $M_{w}$ of PVA 130,000 g/mol, independently of $M_{n}$ of PLLA. In the case of PLLA of $M_{n} 3000 \mathrm{~g} / \mathrm{mol}$, the spheres having diameters under $100 \mathrm{~nm}$ were obtained using PVA of $\mathrm{M}_{\mathrm{w}} 130,000 \mathrm{~g} / \mathrm{mol}$, both at low $\left(600 \mathrm{~min}^{-1}\right)$ and high $\left(1200 \mathrm{~min}^{-1}\right)$ stirring speed. Two maxima of the particle size distribution, corresponding to diameters of the spheres ca. $80 \mathrm{~nm}$ and $160 \mathrm{~nm}$ (Fig. 6), were obtained for PLLA of $M_{n}$ 40,000 and $86,000 \mathrm{~g} / \mathrm{mol}$, respectively. The observations discussed above have suggested that the spheres smaller than $100 \mathrm{~nm}$ most likely do not contain neomycin, whereas the antibiotic is present in the particles having diameters over $150 \mathrm{~nm}$.

\section{Profile of neomycin release from the spheres}

Kinetics of neomycin release from the PLLA spheres was examined in an acidic medium (acetate buffer) and nearly neutral medium (phosphate buffer). Following the hypothesis that neomycin may be contained in spheres having a diameter of at least $150 \mathrm{~nm}$, the examined spheres had diameters of $150 \mathrm{~nm}$ and $200 \mathrm{~nm}$. For each size of the spheres, the degradation of PLLA associated with neomycin release was faster and simultaneously more favorable in the phosphate buffer, which is similar to the physiological range. This result has been considered more important because the $\mathrm{pH}$ of the phosphate buffer is more closely resembling conditions in the organism. Rates of API dissolution from smaller $(150 \mathrm{~nm})$ and larger $(200 \mathrm{~nm})$ spheres were similar; however, the amounts of free antibiotic at the starting point were different. The amounts of free neomycin outside the spheres (i.e., in the aqueous solution and on the surface of spheres) were determined by measuring neomycin concentration at the starting point. A low concentration of neomycin at the starting point proves a high yield of encapsulation and vice versa. From the API dissolution profiles, one could conclude that approx. $70 \%$ of the active substance was encapsulated in $150 \mathrm{~nm}$ spheres, and approx. $90 \%$ in spheres of $200 \mathrm{~nm}$ in diameter. An increase of neomycin concentration in the solution during the experiment, compared to the starting point, is a proof of the presence of the antibiotic in the spheres. It has been found that the time required to complete dissolution of the antibiotic from the polymer matrix is relatively long and reaches approx. $30 \mathrm{~h}$.

\section{Antimicrobial activity of the neomycin-containing spheres}

\section{Tests of activity on a solid medium}

Results of antimicrobial activity against bacteria and yeast obtained from tests on a solid medium have confirmed that neomycin inhibits the growth of all tested microorganisms. The neomycin-containing spheres have shown inhibitory activity against the same strains as the active substance, although less distinct. It was shown that polyL-lactide, and, more precisely, the product of its hydrolysis, i.e., lactic acid and its oligomers (referred to empty spheres), inhibit the growth of $B$. subtilis only (Table 1). It was recognized that the lower activity of neomycin-containing spheres, as compared to the pure substance, represents the occlusion of the antibiotic in the polymer matrix. Due to the necessity of polymer degradation, the release of neomycin from the spheres requires a longer time. This process is advantageous as the slow release of API is the task of polymer spheres as DDS.

\section{Tests of activity in a liquid medium}

Results of the antimicrobial activity tests against bacteria and yeast on a liquid medium were in all cases consistent with those from the tests on a solid medium (Fig. 8). However, the tests in a liquid medium appeared more accurate since the differences of activity between the neomycin-containing spheres and free API were larger. Liquid mediums provided better availability of the examined preparation for the microbial cells, and therefore, they better resemble conditions that naturally prevail in living organisms.

\section{Tests of activity against filamentous fungi}

The tests determined the characteristics of examined preparations against filamentous fungi on a solid medium (Fig. 9). Neomycin inhibits the growth of all kinds of fungi and its lowest activity is observed against $C$. coccodes. Additionally, neomycin-containing spheres did not show toxicity solely against $C$. coccodes; the free antibiotic was 
also the least active against this microorganism. It was found that LA and its oligomers originating from hydrolysis of PLLA (empty spheres) do not show activity against any kinds of fungi. As in bacteria and yeast, the neomycincontaining spheres had weaker inhibitory activity than the free antibiotic, which may be attributed to occlusion of the neomycin in the polymer matrix and slow degradation of the polymer. Based on the above observations, it has been concluded that the neomycin-containing spheres have antimicrobial activity against filamentous fungi.

\section{Conclusions}

It was previously understood that the most desirable spheres for DDS should have minimal diameters $(<100 \mathrm{~nm})$. On the other hand, due to the size and complexity of the neomycin molecule, its encapsulation requires spheres having diameters over $150 \mathrm{~nm}$. This research shows that efficient encapsulation of neomycin requires PLLA of more considerable molecular weight $\left(M_{n} \geq 13,000 \mathrm{~g} / \mathrm{mol}\right)$. Furthermore, in PLLAs of considerable molecular weight, and hence, high viscosity, encapsulation should be performed with intense stirring $\left(1200 \mathrm{~min}^{-1}\right)$. Inadequate process conditions could result in empty spheres (without the antibiotic).

Based on the profile of API dissolution from the PLLA spheres, it was demonstrated that the yield of the active substance encapsulation in the $200 \mathrm{~nm}$ spheres reaches $90 \%$ and in the $150 \mathrm{~nm}$ spheres $-70 \%$. The kinetics of antibiotic release was similar for the $150 \mathrm{~nm}$ and $200 \mathrm{~nm}$ spheres. Considering similar release rates and a larger (90\%) yield of neomycin encapsulation in the larger $(200 \mathrm{~nm})$ spheres, one could conclude that the larger spheres are more suitable for DDS. We also observed neomycin release to be faster at nearly physiological $\mathrm{pH}$ (7.2) than in an acidic medium ( $\mathrm{pH}=4.5)$. The total time of neomycin release from the spheres is relatively long (approx. $30 \mathrm{~h}$ ); hence, it meets the requirements of DDS.

The most important achievement of this study has been the preparation of the neomycin-containing spheres and the demonstration that they have inhibitory activity against bacteria, yeast and filamentous fungi. However, it is weaker than that of the free active substance (controlled release rate).

Up to now, neomycin-containing spheres were not described as a dosage form of this antibiotic. They were considering inhibitory activity against microorganisms and slow dissolution of neomycin. It may be assumed that the application of this DDS would allow for the reduction of adverse effects and could possibly enhance the therapeutic index of the active substance.

\section{ORCID iDs}

Agnieszka Gadomska-Gajadhur

(D) https://orcid.org/0000-0001-7686-1745

Paweł Ruśkowski (D) https://orcid.org/0000-0002-4589-0727

Aleksandra Kruk (D) https://orcid.org/0000-0001-5323-7093

Jolanta Mierzejewska (D) https://orcid.org/0000-0002-9298-8794

\section{References}

1. Kapetanovic IM. Drug Discovery and Development: Present and Future. InTech Open Online. 2011:428-462. doi:10.5772/1179

2. Wilczewska AZ, Niemirowicz K, Markiewicz KH, Car H. Nanoparticles as drug delivery systems. Pharmacol Rep. 2012;64(5):1020-1037. doi:10.1016/S1734-1140(12)70901-5

3. Hoffman A. The origins and evolution of "controlled" drug delivery systems. J Control Release. 2008;132(3):153-163. doi:10.1016/j.jconrel. 2008.08.012

4. Sobczak M, Olędzka E, Kołodziejski W, Kuźmicz R. Polymers for pharmaceutic applications [in Polish]. Polimery. 2007;52(6):411-420.

5. Soliman GM, Szychowski J, Hanessian S, Winnik FM. Robust polymeric nanoparticles for the delivery of aminoglycoside antibiotics using carboxymethyldextran-b-poly (ethyleneglycols) lightly grafted with n-dodecyl groups. Soft Matter. 2010;6(18):4504-4514. doi:10.1039/ COSM00316F

6. Heidary N, Cohen DE. Hypersensitivity reactions to vaccine components. Dermatitis. 2005;16(3):115-120. PMID:16242081

7. Kruk A, Gadomska-Gajadhur A, Ruśkowski P, Przybysz A, Bijak V, Synoradzki L. Optimization of the preparation of neomycin-containing polylactide spheres by mathematical methods of design of experiments [in Polish]. Przem Chem. 2016;95:766-769. doi:10.15199/62. 2016.4.10

8. Nagavarma BVN, Yadav HKS, Ayaz A, Vasudha LS, Shivakumar HG. Different techniques for preparation of polymeric nanoparticles: A review. Asian J Pharm Clin Res. 2012;5(3):16-23.

9. Griffiths G, Nyström B, Sable B, Khuller GK. Nanobead-based interventions for the treatment and prevention of tuberculosis. Nat Rev Microbiol. 2010;8(11):827-834. doi:10.1038/nrmicro2437

10. Rao JP, Geckeler KE. Polymer nanoparticles: Preparation techniques and size-control parameters. Prog Polym Sci. 2011;36(7):887-913. doi:10.1016/j.progpolymsci.2011.01.001

11. Gimpel K, Luliński P, Maciejewska D. Selected technologies to optimize the delivery of active substances in modern drug formulations [in Polish]. Biul Wydz Farm WUM. 2009;3:19-23.

12. Varde NK, Pack DW. Microspheres for controlled release drug delivery. Expert Opin Biol Ther. 2004;4(1):35-51. doi:10.1517/14712598.4.1.35

13. Singh A, Garg Jl, Sharma PK. Nanospheres: A novel approach for targeted drug delivery system. Int J Pharm Sci Rev Res. 2010;5(3):84-88.

14. Szymańska E, Winnicka K. Microspheres: A modern form of controlled-release eye medicine [in Polish]. Farm Pol. 2009;65:378-386.

15. Nowak B, Pająk J. Biodegradation of poly(lactide) (PLA) [in Polish]. Arch Gosp Odpad Ochr Środ. 2010;12:1-10.

16. Gadomska A, Warych I, Ruśkowski P, Synoradzki L. Manufacturing of polylactide nanospheres [in Polish]. Przem Chem. 2014;93(8): 1011-1014. doi:10.12916/przemchem.2014.1311

17. Gadomska-Gajadhur A, Mierzejewska J, Ruśkowski P, Synoradzki L. Manufacturing of paracetamol-containing polylactide spheres [in Polish]. Przem Chem. 2015;94:1676-1678. doi:10.15199/62.2015.10.3

18. Drumright RE, Gruber PR, Henton DE. Polylactic acid technology. Adv Mat. 2000;12(23):1841-1846. doi:10.1002/1521-4095(200012)12: 23<1841::AID-ADMA1841>3.0.CO;2-E

19. Gupta AP, Kumar V. New emerging trends in synthetic biodegradable polymers. Polylactide: A critique. Eur Polym J. 2007;43(10):4053-4074. doi:10.1016/j.eurpolymj.2007.06.045

20. Datta R, Tsai SP, Bonsignore P, Moon SH, Frank JR. Biotechnological production of lactic acid and its recent applications. FEMS Microbiol Rev. 1995;16:221-231.

21. Łukowska-Chojnacka E, Mierzejewska J. Enzymatic hydrolysis of esters containing a tetrazole ring. Chirality. 2014;26(12):811-816. doi:10.1002/ chir.22360 